\title{
10 Co-Production in an Information Age
}

\author{
Albert Meijer
}

\section{TECHNOLOGICAL PROMISE}

In Ramsey County, Minn., you don't have to be a cop to fight crime. In fact, you don't even have to leave your desk. All you have to do is join the county's virtual neighborhood watch network and you'll be able to lookout for suspicious activity from your computer. (Nichols, 2010)

New practices of co-production are being facilitated by the new media. The Ramsey County example is telling: citizens are asked to help the police by monitoring online safety cameras. Thirty cameras have been put up at criminal hot spots, or areas with frequent vehicle break-ins, thefts and assaults. The wireless technology allows law enforcement officers to watch what is going on but the police have a limited number of "eyeballs." To extend their number of "eyeballs," they have created a website (www.ramseycountysheriffwebcop.com) that enables users to gain access to fourteen of the county's surveillance cameras set up in various public areas. If users spot any suspicious activity, they can report this to the local authorities. The authorities can then watch the cameras more closely and dispatch police to the location if this is needed. The citizens help the authorities to focus their attention. Sheriff Bob Fletcher says in an introduction video on the site: "We want you to help us look for suspicious activity" (Nichols, 2010).

Technology holds a similar promise for public service support: On the finance discussion forum, a citizen posts the following question: "I drive 50 miles one way to work, Can I take my fuel cost off on my taxes?" $\mathrm{He}$ receives several answers that all stress that commuting cannot be deducted. "If you are self-employed or you are going to see clients, you can deduct the mileage, and not your fuel costs. If this is just your commute every day, then no, you cannot deduct anything" (Financial Crisis, 2009).

The finance discussion forum enables citizens to obtain public service support from other citizens. Instead of calling the Internal Revenue Service (IRS), they can pose their questions on the forum and they receive various answers. One could argue that this type of activity takes some of the burden of the shoulders of the IRS because citizens are now doing part of the work themselves. Specific questions may still need to be asked to the IRS, but other questions are taken care of by citizens. Public service support is 
no longer the sole responsibility of government: it is co-produced by government and citizens. This new form of public service support is facilitated by web technology.

In essence, co-production is about creating new connections between government and citizens. Fruitful connections can contribute to solving societal problems, such as crime and theft, by improving public service delivery (see Chapter 1). Although co-production has been explored since the 1970s, we are witnessing a new wave of attention for this form of citizen participation. The new media are an important facilitator for new forms of co-production because the costs of connecting to citizens have been reduced drastically and the new technologies create opportunities to interact 24-7. In short, new media hold the promise of strengthening coproduction in an information age.

Will the new media deliver their promise? It is too early to evaluate the effects of technology on co-production between government and citizens. Various forms of experimenting are taking place. New practices are being developed and redeveloped. Enthusiasts inside and outside government are developing ideas to enable citizens to connect in new and meaningful ways to government agencies. These experiments are taking place in policy areas such as social welfare and health care but also in policing and service delivery. On the basis of these experiments, we can provide a preliminary assessment of the value of technology for co-production between government and citizens.

A pure instrumental assessment of new media, however, would provide too narrow a focus. Research into the impact of new media in the public sector has constantly shown that new media do not only have an instrumental but also an institutional effect (Kling and Dunlop, 1991; Snellen and Van de Donk, 1998). Values embedded in the media have an effect on the practices that are carried out through these media. This has been formulated most notably by McLuhan (1964) in his famous phrase "The medium is the message." The safety cameras in Ramsey County may not only strengthen police effectiveness: it may also fundamentally alter the relations between police and citizens. We need to explore these changes as well.

This chapter is based on theories about new media in social practices and hence adds another dimension to the multidisciplinary analysis of co-production. In line with the ambition of this book to show how co-production actually works in practice, it is based on two empirical research projects. The first project is an analysis of the value of websites for co-production in public service delivery (Bekkers and Meijer, 2010). The second project was an analysis of the use of mobile phone technology in the co-production of safety between police and citizens (Bekkers and Meijer, 2010). The empirical research consisted of a combination of qualitative methods. The main part of the research of co-production in public service delivery consisted of an analysis of 150 posts on the forum.werk.nl. Additionally, an interview and a limited survey were carried out. The analysis of co-production of 
safety consisted of an interview, a media analysis and a secondary analysis of two evaluation studies. The empirical findings from these projects are used to enhance our understanding of the role of technology in co-production. What will be the character of co-production in an information age?

This chapter consists of a theoretical and empirical analysis of the relation between new media and co-production. The theoretical part starts with a brief discussion of co-production in general and then proceeds with a more focused discussion of the theoretical role of new media in co-production. The empirical part presents the results of the studies into the coproduction in the domains of public service delivery and safety. The chapter ends with a discussion of the instrumental value and cultural aspects of coproduction in an information age.

\section{CO-PRODUCTION}

Research into co-production of public services has a long history, and strong conceptual papers about co-production of public services were published in the 1970s, 1980s and1990s (Ostrom, 1978; Whitaker, 1980; Parks et al., 1981; Normann, 1984; Ostrom, 1996; Alford, 1998, for overviews see: Bovaird, 2007; Pestoff, 2006). The idea of co-production of public services can be positioned within the wider debate in the scientific and practitioner communities on public services (Bovaird, 2007). The starting point was the traditional, government-centric model of public services that was based on the assumption that civil servants should emphasize the legality and equity of public services. Traditional bureaucrats were not interested in customer satisfaction or citizen input in production services. Bureaucratic procedures were central to public service delivery and correct service delivery was measured by adherence to (legal) procedures. Ostrom reinforces: "For some time, most social scientists have conceptualized public agencies producing human services (police, education, welfare) as the primary producers of these services. This conception relegates the citizen to a passive role" $(1978,102)$.

This model of public service production was challenged by "new public management" (Pollitt, 1990; Hood, 1991; Osborne and Gaebler, 1993; Barzelay, 2001). New public management emphasized the importance of customer satisfaction, and the basic idea was that civil servants should not only strive to follow formal procedures but they should make an effort to serve customers. The private sector was presented as a guiding ideal for making citizens more satisfied with services in the public sector. Osborne and Gaebler (1993) emphasized that an "entrepreneurial spirit" should transform the public sector. A range of publications challenged this idea of public service delivery, and many authors emphasized that public service delivery was fundamentally different from service delivery in the private sector (Pollitt and Bouckaert, 2000). An alternative approach is the so-called "new public services" (Denhardt and Denhardt, 2007). This approach highlights 
the fact that public services are different from private services. Reacting to Osborne and Gaebler's claim that public services should focus on steering and not on rowing, Denhardt and Denhardt emphasize that public services are about serving and not steering.

Whereas both the new public management and new public services focus on the role of governments and civil servants, a different strand of critique on new public management focuses on the role of citizens in the production of public services. The argument here is that in new public management, citizens are generally regarded as consumers, whereas citizens should be regarded as co-producers of public services (Bovaird, 2007). This strand of thinking focuses our attention on an older alternative for a government-centric perspective on public services. The term co-production was originally coined by Ostrom (1978). In the 1990s, Ostrom emphasized that "the great divide between the Market and the State or between Government and Civil Society is a conceptual trap arising from overly rigid disciplinary walls surrounding the study of human institutions" (1996, 85-86). She sees co-production as a core component of most forms of public service delivery.

Renewed attention for co-production of public service delivery has been triggered by technological developments. The success of Internet communities such as Wikipedia and Linux have led to a new wave of attention for the idea of co-production (often referred to a co-creation). The proponents of co-production in the public sector refer to these developments and they suggest that the Internet creates new opportunities for rearranging relations between government and citizens (Eggers, 2005; Tapscott and Williams, 2006). Ideas about co-production have been revitalized by the new Internet technologies.

\section{NEW MEDIA}

How can new media facilitate co-production? Beautiful scenarios of coproduction in an information age have been developed by creative thinkers. A great example of these scenarios is Leadbeater and Cottam's (2007) argument to organize public services in the form of a "user generated state": "A public sector that just treats people as consumers-even well-treated ones-will miss this dimension of participation that is at the heart of the most successful organizational models emerging from the interactive, twoway Internet." They argue that new forms of co-production are the key to revitalizing the public sector.

The potential of these new models has been highlighted, but they are only slowly diffusing into the public sector. The idea of a "user generated state" not only conflicts with bureaucratic standards but also hardly fits within the dominant discourse on technology. The dominant discourse on contributions of information and communication technologies to public 
services has been heavily dominated by new public management and pays little attention to the idea of co-production (Bekkers and Homburg, 2007). Improvements have been sought in improving service to individual customers by enabling 24-7 access, integrating services and connecting services to the experience of users. The basic model underlying these improvements is a relation between a public service provider and an individual consumer. The perspective of co-production opens up the arena to other actors who could possibly play a role in the provision of public services. From this perspective, involvement of citizens, intermediaries and stakeholders strengthens the provision of public services. This idea fits recent shifts in thinking about Internet technology: from the Internet as an information medium to the Internet as a platform for communication and interaction.

The dominant, consumerist ideas about technology in government are being challenged by a coalition of advocates of co-production and social media enthusiasts. Ideas of co-production as developed in the administrative sciences match well with ideas about co-production as they have been developed in the Internet community and by technology gurus (Raymond, 1998; Tapscott and Williams, 2006). Leadbeater and Cottam (2007) state:

Traditional professional public services will be more effective the more they are designed to help and motivate users to generate their own content and solutions. [ ... ] That is why promoting participation should be at the heart of a new agenda for public services. Not participation in formal meeting or governance but participation in service design and delivery.

Wikipedia and Linux are inspiring examples that lead the way toward new models of service production in which services are not only produced for consumers but also by consumers (cf., Toffler, 1980).

The idea of co-production on the Internet has received new attention with the thrust of what has been labeled "Web 2.0" (O'Reilly, 2005). Frissen and colleagues $(2008,62)$ indicate that web 2.0 consists of new platforms for interactions with extensive input from users, integration of knowledge and user participation in the production of web services. One of the core assumptions of web 2.0 is that users generate content. Content is no longer produced and provided by the public service provider but rather being created (i.e., co-produced) in networks and communities. Content is made available to all members of the community and generally stored in an accessible format to create an online interaction platform and repository for the virtual community.

In IT-circles, the instrumental perspective on new media and co-production is dominant: the basic idea is that objectives can be attained more efficiently with new technologies. Media theorists such as McLuhan (1964), Postman (1986) and Winner (1977) emphasize that media should not only be analyzed as instruments to obtain certain objectives because the use 
of media also influences these objectives. McLuhan emphasizes that "the media is the message," Postman stresses that "to a man with a hammer everything looks like a nail" and Winner talks about "reverse adaptation" to indicate that the means shape objectives. Applying their views to the use of new media for co-production in the public sector, we need to analyze not only goal attainment and side effects. A reflective perspective on the emerging new practices is needed to understand the meaning of these new media for shaping relations between citizens and government.

To enhance our understanding of the instrumental value of new media for co-production and to reflect on the changing meaning of it, we investigated emerging practices of co-production in two different domains of government activity: public service support and safety. New practices are described and analyzed in terms of their value for government and citizens. We will present a reflection of changing meanings in the conclusions.

\section{NEW MEDIA AND THE CO-PRODUCTION OF PUBLIC SERVICES}

The first empirical domain in our analysis of new media and co-production is public service support. Public service support is meant to help clients in the process of public service provision. Most government agencies have call centers and a website to provide their clients with the information they need. One can also think of co-production as a form of providing this information. In 2002, the Dutch Agency for Unemployment Benefits started a forum-forum.werk.nl-to enable citizens to ask each other questions and to discuss various issues related to jobs and unemployment. The central idea behind this forum was that public service provision could be improved by enabling citizens to exchange experiences and answer each others' questions. The forum was set up in an open, easy and accessible manner to enable all users to participate, and the agency communicated the existence of the forum to potential users. In their interactions, citizens were assisted by the agency because fourteen employees at the Center for Work and Income spend part of their time moderating discussions at form. werk.nl. Moderators provide valuable answers to the questions that are not answered by other users. An example is the following quote:

If you gain some money from incidental selling of things on e-Bay, that is not a problem. It is wise to contact the agency if you start gaining a profit of 50 Euro or more a month on average. Your contact person will-in contact with you-determine to what extent this counts as additional income and whether this influences your unemployment benefit.

These answers are based on the previously mentioned forum with questions and answers. If a client would call the contact center of the Dutch Unemployment Benefit Agency, he would get the same answer. Moderators also 
organize and connect discussions in the forum. If users show behavior that does not comply with the rules, moderators intervene.

Do the efforts of the agency trigger participation from citizens? Our analysis indicates that there is a small group of active participants and a large group of "lurkers." With nearly 1,000 members of the forum, the forum has a substantive group of users, albeit that this is only a small fraction of the total number of clients of the Center for Work and Income (165,000 in December 2008). The number of active participants is small: 91 members have posted 10 to 50 messages, 47 members have posted more than 50 messages and 2 frequent posters have posted nearly half of all messages. The number of users is not known, but a calculation on the basis of the average total number of visits for certain discussion indicates that the forum attracts thousands of visitors per week. This indicates that the number of people that use the information-lurkers in Internet terms-is much higher than the number of people that post information on the forum.

What is the content of citizens' contributions? In the first place, many users post questions about their personal situations. An example: "Does anybody know what I can tell an employer to convince him that he should hire an employee for 32 hours a week?"

Second, the forum is used to discuss various issues that are related to jobs and benefits. An example is the following poll, which got 5 votes, 32 comments and was visited 14,666 times: "I find it a good idea to create a blacklist or web register or something like that to list employers who exhibit improper behavior in job application procedures."

Third, the forum is used to share personal experiences. Descriptions of experiences do not result in questions to other users but rather in a call for attention and understanding. Mostly users want to share negative experiences but sometimes they also want to share positive experiences.

Critics such as Keen (2007) have emphasized that there are risks in the provision of information by "amateurs": this information may not be as adequate as the information provided by professionals. The forum.werk. $\mathrm{nl}$ does not seem to run this risk because moderators from the government agency can monitor the quality of the answers. The presence of the moderators may have a preemptive effect: in our empirical research, we found no evidence for a lack of quality in the information provided by other users.

What is the value of this form of co-production to the government agency? First, the forum provides an additional channel of interaction with citizens. Moderators provide answers to questions of citizens when these questions cannot be answered by other citizens. Second, the forum provides the agency with additional signals about customer satisfaction. Discussions about overactive marketers, problems with digital systems and improper job ads form triggers for the agency to improve its public services. Third, and probably most interesting, the forum supplies an additional function to the existing forms of service provision in the sense that citizens can provide each other with information that the agency 
cannot. Citizens exchange specific experiences, and they can tell each other how they have dealt with specific situations. Emotional support is also an important additional function that citizens can provide to each other, whereas the agency cannot do this.

Does the forum provide additional value to citizens? Strong quantitative evidence is not available, but the interview with respondents at the government agency and the content analysis provide indications of the value of the forum. Our analysis indeed seems to show that citizens obtain valuable answers to their questions. The second value of the forum could be that the forum enables citizens to exchange experiences with companions. The qualitative analysis shows that many of the postings contain stories about negative experiences of citizens when applying for a job. Reactions are generally understanding and supportive. We note that these discussions may result in a negative atmosphere concerning the issue of finding a job. The third potential value of the forum is support in finding a job. Neither the interview nor the content analysis provide evidence that the forum helps citizens to find a job.

\section{NEW MEDIA AND THE CO-PRODUCTION OF SAFETY}

The second empirical domain in our analysis of new media and co-production is safety. The police need citizens to assist them in their intervening police work, for example, to provide information about the direction in which a criminal has run away. The traditional approach to engaging citizens is to ask bystanders for information. Important limitations of this approach are that only a limited number of bystanders can be reached and that the intervening police officer has to spend his time on gathering information from citizens instead of intervening in a situation by pursuing the criminal.

The Dutch police developed a new system for engaging citizens in intervening police work called Burgernet (Citizens Net). The system was tested on a small scale in 2004 in the city of Nieuwegein and on a larger scale in 2008 in nine Dutch cities. Over the next years, Citizens Net will be implemented in every police department in the Netherlands. The basic idea behind the system is that the police contact citizens over the telephone when they need direct information from them. They can contact them in the so called "golden hour," the time directly after something has been reported.

How does Citizens Net work? Citizens sign up for the system and provide information about their home or work address. The police can contact this network of citizens at this real time: directly after a crime or missing person has been reported, the police can contact citizens to ask for information. Citizens are contacted on the basis of their geographical characteristics. If, for example, a thief has been seen running away in a certain direction, citizens in that area are contacted. The emergency center of the police can start 
a so-called Citizens Net action, which means that a voice or text message is send to all participants to tell them who or what the police are looking for. The following message is an example: "Stolen in Maarssen (a Dutch city): red Volkswagen Golf Cabriolet. License Plate Number: TN-DG-23. If you see this vehicle, please call 112" (Police Nieuwegein, 2010).

The participants receive a new message when the Citizens Net action is terminated. They can also obtain additional information about this action on the Citizens Net website. The website presents information about the results of the action. This may mean that the police are still looking for a suspect, or it can also mean that a lost child has been found. The website shows the number of citizens that have been contacted and the number that has actually been reached. The website does not contain any interactive element: interaction between police and citizens only takes place over the telephone.

The police have three broad objectives for Citizens Net. The first objective is to strengthen the subjective safety, citizens' perception of safety in their own environment. The basic idea is that citizens will feel safer when they can do something about safety. The second objective is to strengthen objective safety. Tracking suspected or missing people faster will enhance the effectiveness of intervening police work. A third objective is to strengthen trust in government and the police. If citizens are engaged in police work, they can be expected to develop a more positive perception of the police.

Citizens' interest in this form of co-production is high, with an average of 4.6 percent of the citizens in the nine cities signing up for participation in Citizens Net. The evaluation of Citizens Net in the nine cities shows that only 24 percent of the participants are less than 36 years old. Most of the participants, 62 percent, are male. This lack of representativeness may not be a problem when it comes to findings lost people, but it may both reflect and affect trust of immigrants and young people in the police and lead to skewed perceptions of safety.

Why do citizens engage in Citizens Net? A citizen's duty and wanting to contribute to the safety of the neighborhood are the strongest motives for engaging in Citizens Net (Van der Vijver et al., 2009, 49). The expected effects in terms of apprehension of criminals and a safer neighborhood along with the idea of a better hold on the safety in the neighborhood score somewhat lower. The latter two can be seen as motives based on group interest. Television broadcasts about Citizens Net reveal another motive that was not measured in the evaluative study by Van der Vijver and colleagues: excitement. In a television program about Citizens Net, a citizen reveals that he found it exciting to receive a phone call from the police and to look out of the window to spot the suspect. De Wit $(2006,47)$ also found that a substantial minority of interviewed participants mentioned excitement as a reason for participating in Citizens Net.

Does this form of co-production contribute to police's effectiveness? The hard contribution of Citizens Net to intervening police work is substantial: 9 percent of all the cases that were qualified as fit for a Citizens Net 
action were solved on the basis of information from this action. This number seems limited in terms of the total number of actions, but it amounts to more than 50 percent of the successful police actions. This indicates that Citizens Net is not a miracle product with which all crimes can be solved, but it certainly forms an important addition to the existing means.

How does Citizens Net affect subjective safety? Do citizens feel safer? The evaluation study indicates that Citizens Net has no effect on citizens feeling of safety in their own neighborhood. Van der Vijver and colleagues $(2009,51)$ argue that these feelings are based on their own perceptions of the neighborhood and are not affected by Citizens Net. At the level of the city, Citizens Net does have a positive effect on subject safety. Van der Vijver and colleagues $(2009,51)$ indicate that these feelings are not based on direct perceptions but on mediated perceptions. These mediated perceptions are influenced by the creation of Citizens Net and the information they receive about how the police work and what the results of these actions are.

\section{TECHNOLOGY MATTERS!}

\section{Instrumental Value}

What have we learned from these cases about the instrumental value of new media for co-production? The forum.werk.nl can clearly be identified as forms of co-production. Value is generated through joint efforts of moderators from the Center for Work and Income and citizens who post questions and experiences and react to each other's postings. This form of co-production is limited to the co-production of public service support. The production of public service delivery, the provision of the benefits, is still carried out by the agency. It is interesting to see that this form of coproduction on the Internet is facilitated by proven technology. There is no need for cutting-edge technology to facilitate new forms of interactions between the agency and its clients.

The empirical findings indicate that the forum.werk.nl supplies an addition to the government-centric form of public service provision in three ways:

- The forum provides an additional channel for public service support. The forum provides an additional channel for obtaining formal information about jobs and unemployment and disability benefits. This information is provided by other citizens and moderators. The forum creates a new channel for providing formal information to citizens.

- The forum provides access to citizens' experiences. The forum also gives citizens access to the experiences of companions. Formal channels of the Center for Work and Income and the Disability Agency cannot provide citizens with this information. Offline channels 
provide the same information, but the forums open up the exchange of experiences to a much larger group of citizens.

- The forum provides a social and emotional function. The forum provides citizens with a channel for sharing experiences. Governmentcentric service provision has a businesslike character and creates few opportunities for delving into social and emotional issues related to being unemployed. The forum gives citizens the opportunity to set up a mutual support structure.

The value and role of the digital forum should not be exaggerated. Less than a percent of the clients of the Center for Work and Income is a member of the forum, and less than one-tenth of a percent of the clients actively participates in the discussions. Even though thousands of people visit the forum and obtain information from it, the forum.werk.nl still plays a limited role compared to other channels of public service provision, such as the telephone and face-to-face meetings.

Citizens Net can also be regarded as a form of co-production because information from the police is combined with information from citizens to strengthen intervening police work. The police direct this form of coproduction: they have all the information from citizens and feed little information back. The website is used to present information about Citizens Net, but it contains little information about the input from citizens. The police deliberately choose to use technology only to facilitate citizen-police interactions and not citizen-citizen interactions. This is an understandable choice in view of the risks of reprisals to individuals, but it also means that citizens do not have the opportunity to contact each other to start new initiatives for improving the safety of the neighborhood. In the end, the police want to stay in control.

The empirical analysis shows that this form of co-production is an important addition to existing instruments in the following ways:

- Citizens Net enhances police effectiveness. Citizen engagement has provided a substantial addition to the existing opportunities for engaging citizens in intervening police work. Citizens Net is not a miracle product, but it certainly forms an important addition to the instruments: it amounts to more than 50 percent of the successful police actions.

- Citizens Net strengthens subjective feelings of safety. Although Citizens Net has no effect on citizens' feeling of safety in their own neighborhood, it does have a positive effect on subjective safety at the city level. This perception is influenced by the creation of Citizens Net and the information citizens receive about the police work and what the results of these actions are.

The advantages of this type of citizen engagement are substantial. The combination of information technology at the side of the police (database with 
information about participants, geographical layer for choosing relevant participants, system for managing Citizens Net actions, Internet site with further information) and (cell) phones at the side of citizens form a perfect couple. This type of technology use does not demand access to technology for citizens or knowledge about complicated systems. Nearly everyone has a telephone and knows how to use it. Technology does not form a barrier to participation.

Although positive effects for police effectiveness and legitimacy were identified, the study also provided information about (potential) risks. These risks build on the normative debate in the literature about the "dystopian dangers of unreflexive communitarism" (Hughes and Rowe, 2007, 318). Negative side effects concern infringements on the privacy of citizens and the risk of practices of vigilantism. Both risks relate to the idea that the benefits of co-production will not equally be divided among citizens. In the practices of co-production in investigative police work, suspects face a deterioration of their position because of the infringements on their privacy. These infringements follow the general trend of prioritizing safety over privacy (Rubenfeld, 2008).

Overall, the findings indicate that technology facilitates new forms of co-production. The forum.werk.nl facilitates new connections between citizens and the public service provider, and Citizens Net facilitates new connections between citizens and the police. Creating the same connections without new media would hardly be possible in view of the numbers of participants and their geographical dispersion. The new media help to create new connections. These connections help to strengthen the effectiveness and efficiency of public service delivery and safety policies. Although these contributions are limited-one should not expect the miracles from co-production through social media that gurus talk about-they present promising venues for improving the work of government.

\section{Co-Production as a Social and Emotional Encounter}

What is the meaning of new media for co-production? The empirical research into the co-production of public service provision highlights a first pattern: a shift from a rational to a more social encounter. Services are not provided to an individualized "homo economicus" but to a "homo sociologicus," who is a member of a community of citizens. Public service provision is positioned within networks of citizens who interact with the government agency, an independent intermediary and each other. What does the Internet do with these interactions? The creation of a forum to facilitate these interactions leads to interesting couplings between domains that are traditionally separated:

- Mixing of information sources. In a traditional system, citizens can obtain information from either government or their peers. In the new 
system, the distinction between these two is fading away. Citizens ask a question, and they can get an answer from either the moderator or a fellow citizen.

- Mixing of functions. In a traditional system, citizens obtain factual information mostly from government agencies and emotional support from their peers. The forum challenges this distinction by creating a virtual space in which both factual information and emotional support is provided.

The value of the forum is that the community of citizens is created. The postings on the forum show that there is the idea of a shared identity based on the fact that they are in the same situation, which is similar to what has been found for patient groups (Madara, 1997). This shared identity, however, can only result in a community when citizens have a communication platform to exchange information and experiences. This community is a partial and not a holistic community in the sense that most members only contact other members on issues related to jobs and benefits. The community consists of networked individuals as indicated by Castells (2001) and Wellman and Haythornthwaite (2000): individuals create new connections, but these do not take the form of traditional communities.

The community of citizens in forum.werk.nl is similar to the many patient groups on the Internet and can be classified as "communities of interest" (Van Bockxmeer, Frissen and Van Staden, 2001). These groups also provide both factual and personal information, as well as informative and emotional functions. Traditional perspectives on co-production emphasize factual and informative functions. Relations between government and citizens are the central focus in many analysis of offline co-production, whereas here we see a shift to citizen-citizen connections and community building. The analysis of the forum.werk.nl clearly shows that public service delivery also entails personal information and emotional functions. Co-production should not only be conceptualized as a rational process but also as a series of social and emotional interactions.

\section{Co-Production as Real-Life Gaming}

What can we learn from a reflection on new practices of co-production in the police? Important for a reflective perspective on co-production in the public sector was the identification of entertainment and excitement as motives for citizens. Intervening police work turns into a real-life game in which everybody can participate. Get a text message, look out of your window and catch the thief. An interesting feature of this new form of co-production is that it seems to be integrated in the life of citizens. Citizens can receive a text message from the police any time of day and wherever they are. The distinction between serious participation and real-life games is thinner than it is in offline co-production. While television may 
reduce everything to a form of entertainment (Postman, 1986), the new media arguably transform all content into a game. Interviews with drivers of tanks in war zones have indicated that these drivers feel that they are in computer game. In the co-production of safety, stakes are not as high, but the impact of new media may be identical.

One can think of several reasons why people play games. A first reason to play games is to kill time and have something to do. Participation in Citizens Net is specifically high among senior citizens. One could assume that these citizens need something to do, and Citizens Net provides them with a useful alternative. A second reason to play games is to have an intellectual challenge. One can play a puzzle, do a sudoku or get involved in Citizens Net. This type of puzzle may be relevant to more investigative police tasks. A third reason to play games is to compete with others and attain a higher social status. The motives for participating in the Citizens' Net seem to indicate that people want to obtain social value, and we could even propose that they want more value than others by presenting relevant information to the police.

The idea that the new media transform co-production into a game has important implications. The police may even have to compete with other "games" to get the attention of citizens. Will they play Dungeons and Dragons or watch the police cameras in Ramsey County? Developing meaningful relations in our "attention economy" (Davenport and Beck, 2001) may be a matter of developing the right games. Issues of privacy and protection of the rights of suspects may become less important in the new forms of online entertainment. Previously, religious duties seemed to have formed the model for citizen participation as secular institutions replaced preexisting religious institutions (Tocqueville, 2000). Visiting police neighborhood meetings was not considered to be "fun," but it appealed to a sense of civic duty, just like going to church (Verba and Nie, 1972). Now these contacts with the police are based on the idea of gaming. Dungeons and Dragons may be the new model for co-production.

\section{CO-PRODUCTION IN AN INFORMATION AGE}

What have we learned from these emerging practices about co-production in an information age? The key lesson is that technology matters in both an instrumental and an institutional sense. Technology facilitates new practices of co-production: new media lower the costs of large scale and dispersed interactions and therefore enable practices of co-production that could hardly be created offline. The new media also transform these practices into more social and more playful interactions: co-production in an information age seems to be less serious than offline co-production. An important question here is what these changes mean for government. Is government capable of developing social and playful interactions? And is 
this a task for government? Or are citizens capable of developing these forms of interactions themselves?

Let us first consider co-production in public service support. Why should governments not leave it to citizens to organize their information provision about public services? The Center for Work and Income has chosen to set up this forum because there was not yet a similar forum available. The forum is fairly active and seems to meet unmet needs (Madara, 1997, 21). An important benefit for the agency was that this also means that they can monitor the discussions and that they can react to rumors and incorrect information. On the other hand, one can question whether government agencies should penetrate the personal sphere of citizens (cf. Habermas, 1984) to improve the provision of public services. Should government agencies be involved in the exchange of personal experiences of citizens? And should government be the one that provides these facilities? The finance discussion forum in the introduction presents an interesting alternative: citizens answer each others' questions without government involvement. One could argue that government should only develop this type of co-production when citizens have not developed a similar platform by themselves.

The considerations may be different when it comes to the domain of safety. Citizens are developing their own communities in the form of neighborhood watches. These communities have much value but do not enable the exchange of information between citizens and the police. This exchange is crucial because citizens and police both hold part of the information and need each other to produce safety. For privacy reasons, the police cannot put their information out in the open, and citizens will also be reluctant to share certain information with anybody else other than the police. These constraints on the exchange of information call for the design of effective forms of co-production. Citizens Net shows that playful interactions can be designed, and these forms of play can contribute to public safety.

In the information age, governments need to reassess the need, opportunities and forms of co-production. Social media enable the construction of new connections between government and citizens, and these connections could hardly be created offline. The value of these connections depends on the policy domain, institutional situation and existence of citizen communities. The challenge for governments is to design forms of co-production that appeal to citizens' motives. The Internet as a virtual space for social support and serious gaming challenges traditional bureaucratic orientations of governments.

\section{REFERENCES}

Alford, J. 1998. A public management road less travelled: Clients as co-producers of public services. Australian Journal of Public Administration 57 (4): 128-137.

Barzelay, M. 2001. The New Public Management. Berkeley: University of California Press. 
Bekkers, V., and V. Homburg. 2007. The myths of e-government: Looking beyond the assumptions of a new and better government. The Information Society 23 (5): 373-382.

Bekkers, V., and A. Meijer. 2010. Cocreatie in de Publieke Sector. Een Verkennend Onderzoek naar Nieuwe, Digitale Verbindingen tussen Overheid en Burger. Den Haag: Boom Juridische Uitgevers.

Bovaird, T. 2007. Beyond engagement and participation: User and community coproduction of services. Public Administration Review 67 (5): 846-860.

Castells, M. 2001. The Internet Galaxy. Reflections on the Internet, Business and Society. Oxford, UK: Oxford University Press.

Davenport, T. H., amd J. C. Beck. 2001. The Attention Economy: Understanding the New Currency of Business. Cambridge, MA: Harvard Business School Press.

Denhardt, J. V., and R. B. Denhardt. 2007. The New Public Service: Serving, Not Steering. Armonk, NY: ME Sharp.

De Wit, E. 2006. Burgernet: Een Trendsetter? Over Burgers en Responsibilisering. Unpublished Master Thesis, Rotterdam, Erasmus University Rotterdam.

Eggers, W. D. 2005. Government 2.0: Using Technology to Improve Education, Cut Red Tape, Reduce Gridlock and Enhance Democracy. Plymouth, UK: Rowman and Littlefield.

Financial Crisis. 2009. Financial Forum>Taxes thread. http://www.financialcrisis2009.org/forum/Taxes/I-drive-50-miles-one-way-to-work-Can-I-take-myfuel-cost-off-on-my-taxes-291931.htm. Retrieved August 2, 2011.

Frissen, V., et al. 2008. Naar een 'User Generated State'? De Impact van Nieuwe Media voor Overheid en Openbaar Bestuur. The Hague: Report for the Dutch Department for the Interior.

Habermas, J. 1984. The Theory of Communicative Action. Cambridge, UK: Polity.

Hood, C. 1991. A public management for all seasons? Public Administration 69 (1): 3-19.

Hughes, G., and M. Rowe. 2007. Neighbourhood policing and community safety: Researching the instabilities of the local governance of crime disorder and security in contemporary UK. Criminology and Criminal Justice 7 (4): 317-46.

Keen, A. 2007. The Cult of the Amateur. How Today's Internet is Killing Our Culture. New York: Doubleday.

Kling, R., and C. Dunlop, eds. 1991. Computerization and Controversy: Value Conflicts and Social Choices. San Diego: Academic Press.

Leadbeater, C., and H. Cottam. 2007. The User Generated State: Public Services $2.0 \mathrm{http}: / / \mathrm{ww} w . c h a r l e s l e a d b e a t e r . n e t / a r c h i v e /$ public-services-20.aspx.

Madara, E. J. 1997. The mutual-aid self-help online revolution. Social Policy 27 (3): 20-26.

McLuhan, M. 1964. Understanding Media: The Extensions of Man. New York: McGraw-Hill.

Nichols, R. 2010. Neighborhood Watch Goes Digital in Ramsey County, Minn. Government Technology. http://www.govtech.com/public-safety/RamseyCounty-Minn-Neighborhood-eWatch.html. Accessed November 22, 2010.

Normann, R. 1984. Service Management. Chichester, UK: John Wiley.

O'Reilly, T. 2005. What is Web 2.0? Design Patterns and Business Models for the Next Generation of Software. www.oreillynet.com/lpt/a/6228. Accessed December 1, 2010).

Osborne, D., and T. Gaebler. 1993. Reinventing Government. New York: Penguin Books.

Ostrom, E. 1978. Citizen participation and policing: What do we know? Nonprofit and Voluntary Sector Quarterly 7 (1-2): 102-108. 
Ostrom, E. 1996. Crossing the great divide: co-production, synergy and development. World Development 24 (6): 1073-1087.

Parks, R. B., P. C. Baker, L. Kiser, R. Oakerson, E. Ostrom, V. Ostrom, S. L. Percy, M. B. Vandivort, G. P. Whitaker, and R. Wilson. 1981. Consumers as coproducers of public services: Some economic and institutional considerations. Policy Studies Journal 9 (7): 1001-1011.

Pestoff, V. 2006. Citizens and co-production of welfare services: Childcare in eight European countries. Public Management Review 8 (4): 503-519.

Pollitt, C. 1990. Managerialism and the Public Services. Oxford, UK: Blackwell.

Pollitt, C., and G. Bouckaert. 2000. Public Management Reform. Oxford, UK: Oxford University Press.

Postman, N. 1986. Amusing Ourselves to Death. New York: Penguin Books.

Raymond, E. S. 1998. The Cathedral and the Bazaar. First Monday 3 (3). firstmonday.org.

Rubenfeld, J. 2008. The end of privacy. Stanford Law Review 61 (1): 101-162.

Snellen, I.Th.M., and W. Van de Donk. 1998. Public Administration in an Information Age. A Handbook. Amsterdam: IOS Press.

Tapscott, D., and A. Williams. 2006. Wikinomics: How Mass Collaboration Changes Everything. New York: Portfolio.

Tocqueville, A. de. 2000. Democracy in America. Chicago: University of Chicago Press.

Toffler, A. 1980. The Third Wave: Democratization in the Late Twentieth Century. New York: Bantam Books.

Van Bockxmeer, H., V. Frissen, and M. Van Staden. 2001. Nieuwe media en gemeenschappen. Delft: TNO Strategie, Technologie en Beleid.

Van der Vijver, K., et al. 2009. Burgernet in de Praktijk. De Evaluatie van de Pilot van Burgernet. Dordrecht: Stichting Maatschappij, Veiligheid en Politie.

Verba, S., Nie, N.H. 1972. Participation in America: Political Democracy and Social Equality. New York: Harper and Row.

Wellman, B. A., and C. Haythornthwaite, eds. 2000. The Internet in Everyday Life. Oxford, UK: Blackwell.

Whitaker, G. 1980. Co-production: citizen participation in service delivery. Public Administration Review 40 (3): 240-246.

Winner, L. 1977. Autonomous Technology: Technics-out-of-Control as a Theme in Political Thought. Cambridge, MA: MIT Press. 